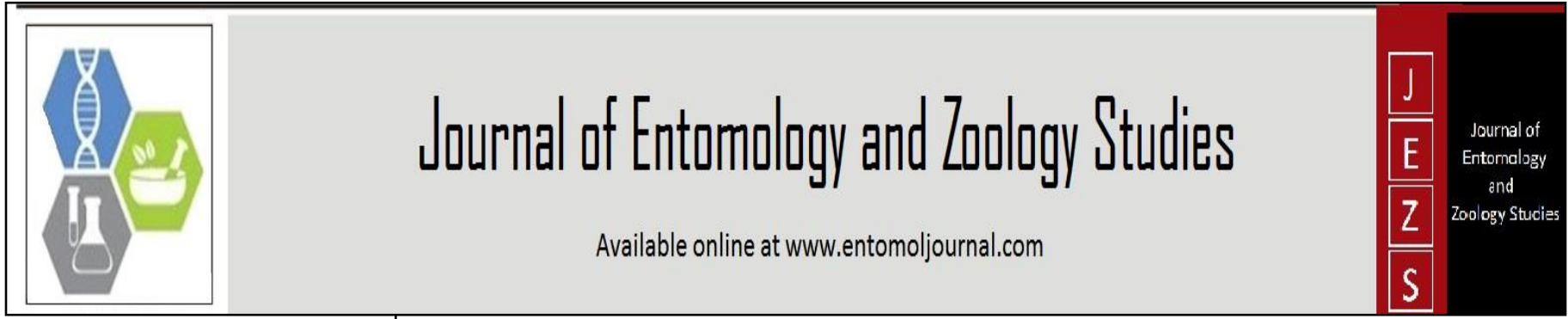

E-ISSN: 2320-7078

P-ISSN: 2349-6800

www.entomoljournal.com JEZS 2021; 9(4): 362-365 (C) $2021 \mathrm{JEZS}$

Received: 19-05-2021

Accepted: 21-06-2021

\section{K Nishanthini}

Department of Entomology,

Faculty of Agriculture

Annamalai University,

Chidambaram, Tamil Nadu,

India

M Kandibane

Department of Agricultural Entomology, Pandit Jawaharlal Nehru College of Agriculture and Research Institute, Karaikal,

U.T. of Puducherry, India

\section{Corresponding Author:}

\section{Kandiban}

Department of Agricultural

Entomology, Pandit Jawaharlal

Nehru College of Agriculture and

Research Institute, Karaikal,

U.T. of Puducherry, India

\section{Seasonal incidence of insect pests of rice at Pajancoa and RI, Karaikal, U.T. of Puducherry}

\section{K Nishanthini and M Kandibane}

DOI: https://doi.org/10.22271/j.ento.2021.v9.i4e.8802

\section{Abstract}

The Seasonal incidence of insect pests of rice were studied with a light trap during Kharif 2019 and Rabi 2019-2020. The results exhibited that yellow stem borer, Scirpophaga incertulas was first observed during $28^{\text {th }}$ meteorological standard week $(0.14)$ and its activity gained momentum from August to November (Kharif 2019) and January to February (Rabi 2019-2020) and reached its highest peak during $43^{\text {rd }}$ MSW (2.86) and green leafhopper, Nephotettix virescens commenced during $47^{\text {th }}$ MSW (1.43) and populations reached its highest level during $1^{\text {st }}$ MSW (4.86) and $4^{\text {th }}$ MSW (5.29). Brown planthopper, Nilaparvata lugens occurred first during $50^{\text {th }}$ MSW $(0.29)$ and its major activity was observed during $1^{\text {st }}$ MSW (2.29) and $3^{\text {rd }}$ MSW (1.86). White leafhopper, Cofana spectra arrived first during $48^{\text {th }}$ MSW (0.29) with highest peak of population during $3^{\text {rd }}$ MSW (1.71) during Rabi 2019-2020.

Keywords: rice, seasonal incidence, light trap, abiotic factors, stem borer, brown planthopper, green leafhopper

\section{Introduction}

Asian cultivated rice Oryza sativa $(2 \mathrm{n}=24)$ is the world's most important food crop and is a primary source of energy for more than one third of world's population. Rice accounts for 35 to $60 \%$ of the calories consumed by three billions Asian people (Khush, 2005) ${ }^{[4]}$. Light trap is an important tool to monitor and minimize the insect pests damage without any toxic hazards (Sharma et al., 2004) ${ }^{[12]}$. Other than this light trap has been used to supplement the knowledge of pest fauna of given locality, geographical distribution and their seasonal activity etc. (Sharma et al., 2010) ${ }^{[11]}$. The forecasting and predication of insect occurrence or outbreak can be made by using light trap. These studies are helpful in the rational and timely application of insecticide which may lead to better and cheaper insect control with least hazards.

\section{Materials and Methods}

Seasonal incidence of major insect pest species of rice was studied with a light trap during Kharif 2019 and Rabi 2019-2020 at Pandit Jawaharlal Nehru College of Agriculture and Research Institute (PAJANCOA \& RI), Karaikal district, U.T. of Puducherry daily. The light trap was allowed to illuminate from $6.00 \mathrm{pm}$ to $9.00 \mathrm{pm}$ to monitor the activity of rice pests alone. The daily trap catch on the seasonal abundance of rice pests was converted into weekly average. Observations of weather data like maximum and minimum temperature, morning and evening relative humidity and rainfall were recorded on daily basis from Agronomy meteorological observatory. The relationship between weather parameters and major pests was determined through correlations.

\section{Results and Discussion}

Seasonal incidence of rice insect pests exhibited that yellow stem borer, S. incertulas appeared first during $28^{\text {th }}$ mean standard week (MSW) (0.14) in the light trap (Table 1) during Kharif 2019. Major activity started from August to November and January to February with three

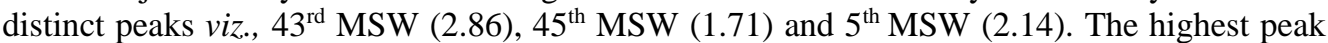
was recorded during $43^{\text {rd }}$ MSW (2.86) in Rabi 2019 2020. Green leafhopper appeared first during $47^{\text {th }}$ MSW (1.43). It had major activity from November to February with three distinct peaks during $48^{\text {th }}$ MSW (4.29), $1^{\text {st }}$ MSW (4.86) and $4^{\text {th }}$ MSW (5.29). The highest peak was recorded during $4^{\text {th }} \mathrm{MSW}$ (5.29). 
Brown planthopper appeared first during $50^{\text {th }}$ MSW (0.29). Its major activity was recorded from December to February with two distinct peaks viz., $1^{\text {st }}$ MSW (2.29) and $3^{\text {th }}$ MSW (1.86). White leafhopper occurred first during $48^{\text {nd }}$ MSW (0.29), and its major activity was registered from December to February, and it had a highest peak during $3^{\text {rd }}$ MSW (1.71). White leafhopper appeared first at $51^{\text {st }} \mathrm{MSW}$ and showed the highest peak of 1.71 at $3^{\text {rd }}$ MSW. However, it had its activity from $51^{\text {st }}$ to $7^{\text {th }}$ MSW during Rabi 2019 -2020. It was inferred from the study that November and December 2019 received the highest rainfall and recorded more than 70 per cent relative humidity which were the favourable and conducive climate for the occurrence of brown planthopper, white leafhopper and green leafhopper during Rabi 2019 -2020 alone.

Sankpal (2011) ${ }^{[9]}$ expressed that the activity of adult moths of yellow rice stem borer was recorded from the third week of August to second week of November with peak levels during the second week of September. Similarly, Justin and Preetha (2013) ${ }^{[3]}$ also stated that the infestation of $S$. incertulas in rice during August-September and December-February during 2008-09, 2009-10 and 2010-11 at Agricultural Research Station, Thirupathisaram, Kanyakumari district. Adiroubane and Raja (2010) ${ }^{[1]}$ also stated that yellow stem borer had high incidence during the months of March (Navarai - Rabi, 2005), August- September (Kuruvai -Kharif, 2006) and October -November (Samba - Rabi, 2006) at Karaikal. Baskaran et al. (2017) ${ }^{[2]}$ expressed that the activity of yellow stem borer was noticed during the first week of August 2016 $\left(31^{\text {st }} \mathrm{MSW}\right.$ ) and reached the maximum during first week of September 2016 (36 $\left.{ }^{\text {th }} \mathrm{MSW}\right)$ and second week of October 2016 (MSW). These findings are in conformity with the present findings.

Sabale et al. (2010) ${ }^{[8]}$ reported that first peak occurrence of green leaf hopper, $N$. virescens during $38^{\text {th }}$ to $41^{\text {st }} \mathrm{MSW}$, the second peak was observed during $45^{\text {th }}$ MSW and the third peak was observed during $52^{\text {nd }}$ to $2^{\text {nd }}$ MSW. Srinavasa et al. (1991) ${ }^{[13]}$ recorded the peak abundance of $N$. virescens in November and May. Meena et al. (2018) ${ }^{[5]}$ stated that green leaf hopper was first recorded during $27^{\text {th }} \mathrm{MSW}$ and activity period of $N$. virescens was observed from July to mid of November with two distinct peaks during $34^{\text {th }}$ and $42^{\text {nd }}$ MSW. These observations are in accordance with the present findings.

Sulagitti et al. (2017) ${ }^{[14]}$ recoded that $N$. lugens appeared in rice crop during first week of August (2 / 10 hills) and its activity gained momentum during the third week of August and a reached highest level during $2^{\text {nd }}$ week of October (32 / 10 hills). Satheesha et al. (2020) ${ }^{[10]}$ reported that appearance of $C$. spectra was observed in $36^{\text {th }}$ MSW with 0.66 hoppers and gradual increase in the population from $37^{\text {th }}$ to $41^{\text {th }} \mathrm{MSW}$ (3.20 to 8.00 hoppers/trap) with first peak was noticed during $39^{\text {th }}$ SMW $(8.00$ hoppers/trap $)$ and $46^{\text {th }}$ MSW (12 hopper/trap).

The correlation study between the meteorological parameters and rice pests indicated that yellow stem borer recorded a significant negative correlation with maximum (-0.58) and minimum temperature (-0.55) and non-significant positive correlation with morning (0.07) and evening RH (0.11) and rainfall (0.14) during Kharif 2019 (Table 2). It was found that yellow stem borer and green leafhopper registered a nonsignificant positive correlation $(0.46,0.08)$ with maximum temperature during Rabi 2019-2020. A non-significant negative correlation $(-0.16,-0.29)$ was observed in brown planthopper and white leafhopper with maximum temperature (Table 3).

A significant negative correlation $(-0.71)$ was recorded in white leafhopper and non-significant negative correlation ($0.41,-0.11,-0.31)$ in yellow stem borer, green leafhopper and brown planthopper with minimum temperature was recorded. A significant positive correlation in green leafhopper $(0.73)$ and non-significant correlation $(0.18,0.12,0.40)$ in yellow stem borer, brown planthopper and white leafhopper were recorded with morning $\mathrm{RH}$.

A significant negative correlation was observed in yellow stem borer (-0.65) and non-significant negative correlation ($0.03,-0.03,-0.29)$ was observed in green leafhopper, brown planthopper and white leafhopper with evening RH. A significant negative correlation with rainfall (-0.57) was observed in yellow stem borer and a significant positive correlation $(0.12,0.24,0.21)$ was observed in green leafhopper, brown planthopper and white leafhopper with rainfall.

Meena et al. (2018) [5] also reported that positive nonsignificant correlation with maximum temperature and nonsignificant negative correlation with rainfall and evening relative humidity were observed in green leafhopper. Nag et al. (2018) ${ }^{[7]}$ stated that population of yellow stem borer showed non-significant positive correlation with maximum temperature $(r=0.07)$ and wind velocity $(r=0.57)$, whereas minimum temperature $(\mathrm{r}=0.83)$, morning relative humidity $(\mathrm{r}$ $=0.80)$, evening relative humidity $(\mathrm{r}=0.82)$, rainfall $(\mathrm{r}=$ $0.64)$, and sunshine hours $(r=-0.88)$ had a significant positive correlation. These findings are in contradiction with the present findings. Mishra et al. (2019) ${ }^{[6]}$ stated that nonsignificant negative correlation with rainfall was observed in green leafhopper. Sulagitti et al. (2017) ${ }^{[14]}$ stated that correlation analysis of $N$. lugens revealed a positive nonsignificant correlation of pest population with rainfall ( $\mathrm{r}$ $=0.292)$, temperature $(\mathrm{r}=0.295)$ and relative humidity ( $\mathrm{r}$ $=0.543$ ). Satheesha et al. (2020) [10] stated correlation analysis, rainfall and number of rainy days had significantly negative effect on the population build up of white leafhoppers. But, maximum temperature, minimum temperature, morning relative humidity had influenced positively and were non-significant. This report is in opposite with the present findings.

\section{Conclusion}

The result of the present study depicted that the yellow stem borer was first observed during $28^{\text {th }} \mathrm{MSW}$ and reached its highest peak during $43^{\text {rd }}$ MSW and green leafhopper commenced during $47^{\text {th }} \mathrm{MSW}$ and populations reached its highest level during $4^{\text {th }}$ MSW. Brown planthopper occurred first during $50^{\text {th }} \mathrm{MSW}$ and its major activity was observed during $1^{\text {st }}$ MSW. White leafhopper arrived first during $48^{\text {th }}$ MSW with highest peak of population during $3^{\text {rd }} \mathrm{MSW}$. 
Table 1: Seasonal incidence of insect pests of rice during Kharif 2019 and Rabi 2019-2020 (weekly average)

\begin{tabular}{|c|c|c|c|c|c|c|c|c|c|}
\hline \multirow[b]{2}{*}{ Mean Standard week } & \multicolumn{4}{|c|}{ Rice pests } & \multicolumn{5}{|c|}{ Meteorological parameters } \\
\hline & \begin{tabular}{|c|} 
Yellow \\
Stem borer
\end{tabular} & $\begin{array}{c}\text { Green leaf } \\
\text { hopper }\end{array}$ & $\begin{array}{c}\text { Brown plant } \\
\text { hopper }\end{array}$ & \begin{tabular}{|c|} 
White leaf \\
hopper
\end{tabular} & $\begin{array}{c}\text { Max. Temp } \\
(\text { (0C) }\end{array}$ & $\begin{array}{c}\text { Min. Temp } \\
(0 \mathrm{C})\end{array}$ & $\begin{array}{c}\text { Max. RH } \\
(\%)\end{array}$ & $\begin{array}{c}\text { Min. RH } \\
(\%)\end{array}$ & $\begin{array}{c}\text { Rain Fall } \\
(\mathrm{mm})\end{array}$ \\
\hline \multicolumn{10}{|c|}{ Kharif 2019} \\
\hline 19th (May 6-12) & 0.00 & 0.00 & 0.00 & \begin{tabular}{|l|}
0.00 \\
\end{tabular} & 38.71 & 27.44 & 80.43 & 49.00 & 0.00 \\
\hline 20th (May 13-19) & 0.00 & 0.00 & 0.00 & 0.00 & 38.67 & 28.19 & 82.71 & 51.29 & 0.00 \\
\hline 21th (May 20-26) & 0.00 & 0.00 & 0.00 & 0.00 & 38.37 & 28.49 & 82.00 & 47.29 & 0.00 \\
\hline 22th (May 27-Jun 2) & 0.00 & 0.00 & 0.00 & 0.00 & 38.94 & 28.76 & 77.57 & 49.14 & 0.00 \\
\hline 23th (Jun 3-9) & 0.00 & 0.00 & 0.00 & 0.00 & 38.11 & 28.57 & 76.00 & 51.86 & 0.00 \\
\hline 24th (Jun 10-16) & 0.00 & 0.00 & 0.00 & 0.00 & 39.44 & 28.37 & 68.00 & 37.86 & 0.00 \\
\hline 25th (Jun 17-23) & 0.00 & 0.00 & 0.00 & 0.00 & 38.97 & 28.99 & 65.14 & 37.43 & 0.00 \\
\hline 26th (Jun 24-30) & 0.00 & 0.00 & 0.00 & 0.00 & 38.37 & 27.06 & 70.57 & 35.43 & 1.57 \\
\hline 27th (Jul 1-7) & 0.00 & 0.00 & 0.00 & 0.00 & 38.19 & 27.50 & 69.71 & 37.71 & 0.00 \\
\hline 28th (Jul 8-14) & 0.14 & 0.00 & 0.00 & 0.00 & 36.66 & 26.46 & 79.43 & 52.00 & 2.29 \\
\hline 29th (Jul 15-21) & 0.43 & 0.00 & 0.00 & 0.00 & 36.41 & 26.37 & 77.43 & 51.57 & 2.64 \\
\hline 30th (Jul 22-28) & 0.43 & 0.00 & 0.00 & 0.00 & 36.56 & 26.54 & 75.14 & 44.43 & 0.00 \\
\hline 31th(Jul 29-aug 4) & 0.57 & 0.00 & 0.00 & 0.00 & 37.29 & 27.14 & 74.43 & 43.14 & 0.00 \\
\hline 32th (Aug 5- 11) & 1.00 & 0.00 & 0.00 & 0.00 & 36.81 & 26.76 & 71.57 & 41.71 & 0.07 \\
\hline 33th (Aug 12-18) & 1.14 & 0.00 & 0.00 & 0.00 & 36.04 & 25.64 & 81.71 & 52.14 & 3.79 \\
\hline 34th (Aug 19-25) & 0.14 & 0.00 & 0.00 & 0.00 & 34.61 & 24.64 & 89.86 & 58.71 & 11.21 \\
\hline 35th (Aug 26-sep1) & 0.43 & 0.00 & 0.00 & 0.00 & 34.90 & 26.39 & 76.14 & 51.00 & 0.00 \\
\hline 36th (Sep 2-8) & 1.14 & 0.00 & 0.00 & 0.00 & 35.63 & 26.14 & 78.00 & 50.71 & 2.06 \\
\hline 37th (Sep 9-15) & 0.43 & 0.00 & 0.00 & 0.00 & 35.09 & 24.53 & 89.29 & 57.43 & 15.33 \\
\hline 38th (Sep 16-22) & 1.57 & 0.00 & 0.00 & 0.00 & 33.33 & 25.24 & 91.00 & 68.14 & 8.14 \\
\hline 39th (Sep 23-29) & 0.57 & 0.00 & 0.00 & 0.00 & 32.30 & 24.81 & 87.71 & 72.29 & 14.19 \\
\hline 40th(Sep 30- Oct 6) & 1.14 & 0.00 & 0.00 & 0.00 & 33.86 & 25.60 & 86.00 & 66.43 & 0.50 \\
\hline \multicolumn{10}{|c|}{ Rabi 2019-2020 } \\
\hline 41th (Oct 7-13) & 1.43 & 0.00 & 0.00 & \begin{tabular}{|l|}
0.00 \\
\end{tabular} & 32.87 & 25.77 & 87.29 & 64.57 & 0.14 \\
\hline 42th (Oct 14-20) & 2.29 & 0.00 & 0.00 & 0.00 & 31.00 & 24.97 & 92.71 & 78.43 & 15.93 \\
\hline 43th (Oct 21-27) & 2.86 & 0.00 & 0.00 & 0.00 & 31.70 & 24.76 & 90.86 & 74.43 & 15.13 \\
\hline 44th(Oct 28- Nov 3) & 1.57 & 0.00 & 0.00 & 0.00 & 31.07 & 23.51 & 92.71 & 78.14 & 16.93 \\
\hline 45th (Nov 4-10) & 1.71 & 0.00 & 0.00 & 0.00 & 33.30 & 24.70 & 91.00 & 64.00 & 15.50 \\
\hline 46th (Nov 11-17) & 0.29 & 0.00 & 0.00 & 0.00 & 31.40 & 24.50 & 93.00 & 68.00 & 58.00 \\
\hline 47th (Nov 18-24) & 0.00 & 1.43 & 0.00 & 0.00 & 30.10 & 23.70 & 93.00 & 83.00 & 174.50 \\
\hline 48th(Nov 25- Dec1) & 0.00 & 4.29 & 0.00 & 0.29 & 30.20 & 24.00 & 93.00 & 83.00 & 263.50 \\
\hline 49th (Dec 2-8) & 0.00 & 3.14 & 0.00 & 0.29 & 29.60 & 23.40 & 91.00 & 77.00 & 127.40 \\
\hline 50th (Dec 9-15) & 0.14 & 1.14 & 0.29 & 0.00 & 29.70 & 22.60 & 87.00 & 72.00 & 42.50 \\
\hline 51th (Dec 16-22) & 0.29 & 2.29 & 0.14 & 0.29 & 29.60 & 23.20 & 93.00 & 76.00 & 28.00 \\
\hline 52th (Dec 23- 29) & 1.00 & 4.43 & 0.29 & 0.43 & 29.40 & 22.40 & 94.00 & 75.00 & 120.50 \\
\hline 1st (Dec 30-Jan 5) & 0.43 & 4.86 & 2.29 & 0.57 & 30.90 & 23.60 & 92.00 & 71.00 & 4.00 \\
\hline 2nd (Jan 6-12) & 1.00 & 3.14 & 1.57 & 1.14 & 29.90 & 20.50 & 93.00 & 68.00 & 2.50 \\
\hline 3rd (Jan 13-19) & 0.43 & 4.86 & 1.86 & 1.71 & 30.19 & 21.19 & 91.71 & 68.00 & 0.79 \\
\hline 4th (Jan 20-26) & 1.43 & 5.29 & 0.43 & 1.43 & 30.26 & 21.44 & 94.57 & 66.00 & 0.00 \\
\hline 5th (Jan 27- Feb 2) & 2.14 & 5.00 & 0.00 & 1.14 & 30.69 & 20.93 & 93.43 & 55.57 & 0.00 \\
\hline 6th (Feb 3-9) & 1.86 & 3.29 & 0.29 & 0.43 & 30.64 & 21.13 & 92.57 & 61.14 & 0.29 \\
\hline 7th (Feb 10-16) & 0.57 & 2.00 & 0.00 & 0.29 & 31.03 & 21.74 & 88.00 & 60.14 & 0.00 \\
\hline 8th (Feb 17-23) & 1.29 & 0.86 & 0.00 & 0.00 & 31.47 & 22.13 & 87.43 & 57.29 & 0.50 \\
\hline 9th (Feb 24- Mar 1) & 0.86 & 0.29 & 0.00 & 0.00 & 31.78 & 22.67 & 92.83 & 58.00 & 0.00 \\
\hline
\end{tabular}

Table 2: Correlation of meteorological parameters against the population of major rice pests during Kharif 2019

\begin{tabular}{|c|c|c|}
\hline Sl. No. & Parameters & Population of yellow stem borer \\
\hline 1. & Maximum temperature $\left({ }^{0} \mathrm{C}\right)$ & $-0.58^{*}$ \\
\hline 2. & Minimum temperature $\left({ }^{0} \mathrm{C}\right)$ & $-0.55^{*}$ \\
\hline 3. & Morning relative humidity $(\%)$ & 0.07 \\
\hline 4. & Evening relative humidity $(\%)$ & 0.11 \\
\hline 5. & Rainfall $(\mathrm{mm})$ & 0.14 \\
\hline
\end{tabular}

\footnotetext{
‘*’ significance at 0.0 .05 level
}

Table 3: Correlation of meteorological parameters against the population of major rice pests during Rabi 2019 -2020

\begin{tabular}{|c|c|c|c|c|c|}
\hline \multirow{2}{*}{ Sl. No. } & \multirow{2}{*}{ Parameters } & \multicolumn{4}{|c|}{ Population of } \\
\cline { 3 - 6 } & & Yellow stem borer & Green leafhopper & Brown planthopper & White leafhopper \\
\hline 1. & Maximum temperature $\left({ }^{0} \mathrm{C}\right)$ & 0.46 & 0.08 & -0.16 & -0.29 \\
\hline 2. & Minimum temperature $\left({ }^{0} \mathrm{C}\right)$ & -0.41 & -0.11 & -0.31 & $-0.71^{*}$ \\
\hline 3. & Morning relative humidity $(\%)$ & 0.18 & $0.73^{*}$ & 0.12 & 0.40 \\
\hline 4. & Evening relative humidity $(\%)$ & $-0.65^{*}$ & -0.03 & -0.03 & -0.29 \\
\hline
\end{tabular}




\begin{tabular}{|c|c|c|c|c|}
\hline 5. & Rainfall $(\mathrm{mm})$ & $-0.57 *$ & $0.12 *$ & $0.24 *$ \\
\hline
\end{tabular}

'*' significance at 0.0 .05 level

\section{References}

1. Adiroubane D, Raja K. Influence of weather parameters on the occurrence of rice yellow stem borer, Scirpophaga incertulus (Walker). Journal of Rice Research 2010;3(1):5-9.

2. Baskaran RKM, Sharma KC, Kumar J. Seasonal and relative abundance of stem borer and leaf folder in wet land rice eco-system. Journal of Entomology and Zoology Studies 2017;5(2):879-884.

3. Justin CGL, Preetha G. Seasonal incidence of rice yellow stem borer, Scirphophaga incertulas (Walker) in Tamil Nadu. Indian Journal of Entomology 2013;75(2):109112.

4. Khush GS. What it will take to Feed 5.0 Billion Rice consumers in 2030. Plant Molecular Biology 2005;59:16.

5. Meena SK, Sharma AK, Rajesh A. Seasonal incidence and population dynamics of major insect pest species of paddy collected in light trap in relation to weather parameters. International Journal of Current Microbiology and Applied Science 2018;7(8):1705-1715.

6. Mishra YK, Sharma AK, Bhowmick AK, Saxena AK, Kurmi A. 2019. Seasonal incidence of insect pest species of paddy collected through light trap. International Journal of Current Microbiology and Applied Science 2019;8(04):381-393.

7. Nag S, Chaudhary JL, Shori SR, Netam J, Sinha HK. Influence of weather parameters on population dynamics of yellow stem borer (YSB) in rice crop at Raipur. Journal of Pharmacognosy and Phytochemistry 2018;SP4:37-44.

8. Sabale JP, Das C, Samui RP. Influence of weather factors on light trap catches of green leaf hopper at Pattambi, Kerala. Journal of Agrometeorology 2010;12(1):108-110.

9. Sankpal ND. Seasonal occurrence and management of major insect pests of paddy (Oryza sativa L.) under middle Gujarat conditions. M. Sc. (Agri.) thesis, Anand Agricultural University, Anand, Gujarat 2011.

10. Satheesha HY, Vijay Kumar L, Shivaray Navi, Raveendra HR, Somu G. Incidence of leafhoppers in rice in relation to meteorological parameters. International Journal of Chemical Studies 2020;8(6):1089-1092.

11. Sharma AK, Barche S, Mishra PK. Pest and predatory insect species inhabiting paddy ecosystem in Jabalpur, Madhya Pradesh collected with the help of light traps. Pest Management and Economic Zoology 2010;18(1/2):125-133.

12. Sharma MK, Pandey V, Singh RS, Singh RA. A study on light trap catches of some rice pests in relation to meteorological factors. Sinet Ethiopian Journal of Science 2004;27(2):165-170.

13. Srinavasa N, Viraktamath CA, Sathyanarayana J. Relative abundance of major insect pests of rice in light trap and their incidence in the field. Indian Journal of Entomology 1991;53(4):603-607.

14. Sulagitti A, Raghuraman M, Sai Reddy MS, Sandeep KS. Seasonal variation in major insect pests incidence on rice and impact of various abiotic factors on their incidence under Varanasi conditions. Journal of Entomology and Zoology Studies 2017;5(3):1060-1063. 